\title{
Ulkoisen ja sisäisen suhteesta
}

\author{
- vastinetta Keijo Räsäsen ja Janne Tienarin vastineeseen \\ (Aikuiskasvatus 3/2007)
}

$\mathrm{J}_{\mathrm{o}}$ ohtamis- ja organisaatiotutkija Keijo Räsäsen ja Janne Tienarin vastine artikkeliini Tieteellisyys kanto johtamiskoulutuksen kaskessa tarjoaa runsaasti alkuja ja aiheita jatkokeskustelulle. Epäilemättä osasyy tähän on siinä, että tekstini sekoitti yhteen "vellit, puurot ja lantrinkit", kuten he hauskasti huomauttavat. Kohde vietteli kehittelemään juonteita, joiden yhteys tarkastelun varsinaiseen tarkoitukseeni olisi kaivannut selvempää osoittamista. Tekstini olisi kaivannut lisää kliinisyyttä ja disipliinisyyttä.

Tarkoitukseni ei ollut kirjoittaa niinkään MBAtutkinnosta tai kauppakorkeakouluista tai liiketaloustieteellisestä tutkimuksesta. Halusin pikemminkin hyödyntää niitä tältä kentältä-MBA, kauppakorkeakoulutus, erityisesti johtaminen tulevien tai sen paremmin tuntevien tutkijoiden kirjoituksia ja havaintoja, jotka antoivat osviittaa siitä, ettei tieteen, tutkimuksen ja yliopistollisen opetuksen keskinäissuhde ole niin yksioikoinen tai armaan auvoinen kuin yleensä annetaan olettaa. Tiede ja ylin opetus ovat monella tavalla ristivetoisia, mahdollisesti jopa perustavalla tavalla yhteensovittamattomia. Minusta keisari akateeminen koulutus - näytti laittavan alus- ja päällysvaatteet päälleen väärässä järjestyksessä; koulutustehtävä on astunut yli tutkimustehtävän yliopistollisen opetuksen lähtökohtana. Vastineessa ruodittiin sitten omien vetimieni kelpoisuutta.

Artikkelini käsikirjoitusversio ei sisältänyt viitteitä aikaisempiin teksteihini. En myöskään sijoittanut sitä mihinkään tieteellisen kirjoittamisen luokkaan. Vastineen valossa artikkelini ymmärtäminen näytti kuitenkin vaativan tällaista kategorisointia. Professorit Keijo Räsänen ja Janne Tienari arvasivatkin asiantuntevasti, että tekstini tulee heidän oman maaperänsä - johtamis- ja organisaatiotutkimus - ulkopuolelta. Sen kritiikki on täten ulkoista. Samalla kun tämä rajanveto tarjosi heille analyyttisia välineitä - näkökulma, positio, asetelma jne. - tarttua tekstiini, hämmensi se myös artikkelini varsinaista tarkoitusta eli sekoitti edelleen puuroja, vellejä ja lantrinkeja siinä.

Minua ovat kiehtoneet tällaiset rajat ja rajanvedot juuri tieteen ja tutkimuksen piirissä. Niihin liittyy vallankäyttöä, mielivaltaisuutta ja valtaa yli mielten. Rajoja naturalisoidaan, väännetään ja vääristellään. Naturalisointi tässä yhteydessä tarkoittaa erityisesti ideaa sellaisesta "omasta" tutkimuskohteesta, joka nähdään todellisuuden itsensä antamaksi, ei esimerkiksi sosiaaliseksi konstruktioiksi, kirjoittamisen ja keskustelemisen perinteeksi, osaksi yliopistobyrokratiaa, vallankäytöllä ylläpidetyksi illuusioksi, huonoksi sopimukseksi tms.

Kaipa me kaikki valvomme monenlaisia rajoja lähes kaiken aikaa. Jokainen halunnee olla sisällä jossakin ja on siksi valmis tekemään osansa ”rajatyöstä” eli osoittamaan missä määrin tai miltä osin itse kukakin on milloinkin ulkona tai sisällä. Rajanvetoihin ryhtymistä on kuitenkin hyvä aina harkita. Voimme vetää rajoja eri tavoin, mutta mistä tiedämme, milloin ne menevät todellisten "liitoskohtien” mukaisesti tai mitä siitä seuraa, että teemme rajaukset oman mielemme rajoja noudattaen? Toiset tulevat sisälle rajatuiksi ja toiset ulos, mutta miten mielivaltaisia, toivottavia tai perusteltavissa olevia tällaiset rajanvedot milloinkin ovat. Akateemisen johtamiskoulutuksen ongelma voi hyvin löytyä positivismin hallitsevuudesta, mutta toisenlaisten rajanvetojen alla pääongelma piilee tieteen ja korkeakoulutuksen keskinäissuhteessa. Onko siis positivismin syyttämiseen ja positivistien jäljittämiseen käytetty aika varmasti hyvin käytettyä aikaa?

Mitähän arvon vuorovaikutustutkijat olisivat nostaneet vastineessaan esiin, jos olisin "todella” osoittautunut - mitä se sitten tarkoittaisikaan - filosofointiin taipuvaiseksi luonnontieteilijäksi, kuten he aluksi ajattelivat. Entä jos olisinkin ollut "oikea” organisaatio- ja johtamistutkija? Oliko nyt todentunut tilanne, siis tietämätön ulkopuolinen 
vs. kaksi johtamisen opetuksesta ja tutkimuksesta vastaavaa professoria, omiaan kirvoittamaan viimeksi mainituilta pienimuotoisen opetuksellisen luennon aihepiiristä. Sehän osoittaa sekä pedagogista hyväntahtoisuutta ("täällä asuu hyviä, oman alueensa tietäviä ihmisiä”) että rajaa tiedon ja tietämättömyyden välillä ("Vesa Huotari ei asu täällä”). Tiedän nyt kolkuttaneeni johtamisja organisaatiotutkijoiden valtakunnan porttia. Muutkin vastineen lukijat tietävät tämän. Kaikki ovat samalla saaneet rautaisannokset myös siitä, millaista lukeneisuutta sisäänpääsy johtamis- ja organisaatiotutkimuksen kentälle ja elo siellä edellyttää. Kiitos siitä!

Erityisen kiitollinen olen kuitenkin artikkeliani kommentoineiden johtamistutkijoiden tiedosta, ettei johtamisesta ole löydettävissä mitään rakenteita tai lainalaisuuksia. Olen kuitenkin lievästi huolestunut mahdollisuudesta, ettei johtamistakaan voida löytää mistään. Ehkä nämä kaksi asiaa liittyvät jotenkin toisiinsa. Minua huolestuttaa erityisesti se, jos tällainen "johtamisen haihtuminen” ei millään tavalla heijastu johtamisen yliopistollisen tutkimuksen ja opetuksen volyymiin tai käsityksiin sen laadukkuudesta. Jollei odotettua yhteyttä tutkimuksen ja tutkimukseen perustuvan opetuksen välillä ei todellisuudessa ole, on jossakin vikaa.

Aikaisemmat johtamisen tutkijasukupolvet saattoivat hyvinkin syyllistyä katteettoman shekin kirjoittamiseen, kun he lupasivat tieteellisen tutkimuksen päällystävän tietä parempaan tulevaisuuteen luomalla "johtamistieteilijän”. Minusta näyttää nyt siltä, että Räsänen ja Tienari tämän sukupolven työn jatkajina yrittävät välttää vastuunsa ja pelastautua julistautumalla johtamis- ja organisaatiotutkijoiksi. Tulemmeko ehkä seuraavaksi tietämään, ettei organisaatioistakaan ole löydettävissä mitään rakenteita tai lainalaisuuksia eikä juuri kukaan tosissaan edes etsiskele mitään tällaisia. Jos tästäkään tiedosta ei olisi estämään tai edes hidastamaan organisaatiotieteen ja tutkijoiden institutionaalista menestymistä yliopistolaitoksessa, niin mitä meidän oikein pitäisi ajatella tieteellisen tutkimuksen ja yliopistollisen koulutuksen keskinäissuhteesta?

On lähinnä sattuma, että pohdintani korkeakoulutuksen ja tieteen suhteesta ja tekstit, joissa ruodittiin johtamisen opetusta ja tutkimusta kauppakorkeakoulutuksessa, tapasivat toisensa ja johtivat tässä puheena olevan artikkelin syntyyn. Pyrkimykseni lisätä ymmärrystä modernin yliopis- ton rakenteesta kaukana kirjoitettujen puheenvuorojen pohjalta oli toki osoitettu kaikkeen yliopistolliseen opetukseen, siis myös akateemiseen johtamiskoulutukseen Suomessa (jotakin uutta ja jotakin universaalia). Minulle liiketoimintaan ja johtamiseen liittyvä tutkimus, opetus ja koulutus oli kelpo tapaus, ei mikään halveksinnan aihe. Sen kautta sopi pyrkiä paremmin ymmärtämään suhdetta, josta uskoin oman aikamme yliopiston luonteen osaltaan juontuvan. Tarkastelukehyksessäni kauppakorkeakoulujen johtamiskoulutus on siis "sisällä".

Olenkin pahoillani siitä, että artikkelini tarkoitus jäi Keijo Räsäsen ja Janne Tienarin tarkasteluhorisontin ulkopuolelle. Vika ei ole heissä. He näkevät ongelmat yhtäällä, minä toisaalla. Minun vain olisi pitänyt pystyä kirjoittamaan asiani auki selvemmin ja ymmärrettävämmin.

\section{Vesa Huotari}

